\title{
Excessos, exceccão e ordem: entraves para a construção democrática pós-transição
}

\author{
Excesses, exception and order: obstacles to the post-transitional democratic construction \\ Excessos, excepcion y orden: enclaves para la construcción democrática post-transicion
}

\author{
Pedro Rolo Benetti \\ Universidade de São Paulo. São Paulo, SP, Brasil.
}

\begin{abstract}
Resumo
O presente trabalho pretende discutir, por meio da análise de fontes, como o discurso militar, em dois diferentes momentos, manteve dentre suas características uma articulação entre as noções de excessos, exceção e ordem. Em defesa de uma concepção vaga, mas ativa de ordem, eles se engajaram em processos repressivos que organizaram parcelas do aparelho do Estado para o uso sistemático da violência. Esses processos aparecem no discurso ora como excessos cometidos na ponta do sistema, ora como exceções legítimas ao arcabouço legal, uma vez que a defesa da ordem por vezes exige o emprego de expedientes não previstos legalmente, em particular quando a situação é análoga à uma guerra. Os discursos que permitem perceber essa articulação foram buscados nas discussões em torno das forças armadas do Estado na constituinte de 1987-1988 e, mais adiante, nos depoimentos prestados à Comissão Nacional da Verdade (CNV). Transição e justiça transicional aparecem aqui interpeladas pelas narrativas que justificam, em um momento como no outro, o emprego continuado da violência.
\end{abstract}

Palavras-chave: Violência. Transição. Discursos.

\begin{abstract}
The present work intends to discuss, through the analysis of sources, how military discourse, at two different times, kept among its characteristics an articulation between the notions of excesses, exception and order. In defense of a vague but active conception of order, they engaged in repressive processes that organized portions of the State for the systematic use of violence. These processes appear in their discourse sometimes as excesses committed at the end of the system, sometimes as legitimate exceptions to the legal framework, since the defense of order sometimes requires the use of legally unforeseen resources, particularly when the situation is analogous to a war. The speeches that allow us to perceive this articulation were sought in the discussions around of the State Armed Forces in the 1987-8 constituent and, thereafter, in the statements given to the National Truth Commission (CNV). Transition and transitional justice appear here challenged by the narratives that justify, at one time and another, the continued use of violence.
\end{abstract}

Keywords: Violence. Transition. Discourses.

\section{Resumen}

El presente trabajo pretende discutir, a través del análisis de fuentes, cómo el discurso militar, en dos momentos diferentes, ha mantenido entre sus características una articulación entre las nociones de excesos, excepción y orden. En defensa de una concepción vaga pero activa de orden, se comprometieran con procesos represivos que organizaron sectores del Estado para el uso sistemático de la violencia. Estos procesos aparecen en el discurso a veces como excesos cometidos en la punta del sistema, a veces como excepciones legítimas al marco legal, ya que la defensa del orden por veces requiere el uso de herramientas no previstas legalmente, particularmente cuando la situación es análoga a una guerra. Los discursos que permítanos percibir esta articulación buscada en las discusiones alrededor de las Fuerzas Armadas del Estado en la constituyente 1987-8 y, posteriormente, en las declaraciones a la Comisión Nacional de la Verdad (CNV). Transición y la justicia transicional aparecen aquí desafiadas por las narrativas que justifican, en un momento u otro, el uso continuado de la violencia.

Palavras clave: Violencia. Transicion. Discursos. 


\section{Introdução}

Sempre que o termo transição é empregado, evoca-se algum tipo de articulação entre passado, presente e futuro. Os processos de transição sempre se apresentam em um jogo tenso na relação com um passado imediato, anunciando um futuro que seja marcado pela superação de elementos considerados problemáticos naquele momento anterior. O presente, nesse registro, não é mais do que o ponto de conexão entre essas duas etapas antagônicas.

A noção de justiça de transição, hoje empregada fartamente por acadêmicos, operadores do direito, profissionais de organizações internacionais $\mathrm{e}$ burocratas do Estado em diversos lugares do mundo, busca estabelecer uma série de passos e condições para que esse presente funcione efetivamente como ponto de passagem, enterrando antigas estruturas do passado e abrindo caminho às novas configurações políticas, sociais e culturais no futuro. Não era outro o objetivo dos teóricos da transição - o que veio a ser conhecido como transitologia, nas décadas de 1970, 1980 e 1990. Tratava-se, também naquele momento, de definir uma série de passos a serem dados, parâmetros a serem alcançados e entraves a serem removidos na direção de um horizonte percebido como livre e democrático. Se Renato Lessa ${ }^{1}$ nos lembra que todo conhecimento político carrega normatividade, nos trabalhos elaborados nos marcos da transitologia ou, posteriormente, da justiça de transição, não é diferente. As análises vêm sempre acompanhadas de sugestões da melhor direção a se seguir.

Nas últimas duas décadas, diversas redes e organizações surgiram ao redor do mundo defendendo modelos de justiça transicional, como o International Center for Transitional Justice ou, em nível regional, a Rede Latino-Americana de Justiça de Transição ${ }^{2}$. Também a Organização das Nações Unidas (ONU) atentou para a centralidade da agenda, quando seu secretário-geral lançou, em março de 2010, um guia de 9 princípios para uma abordagem das Nações Unidas ao tema. Soma-se a essa o documento "Transitional Justice and Economic, Social and Cultural rights"3, publicado em 2014 pelo escritório do Alto Comissariado em Direitos Humanos da ONU.

\footnotetext{
1 Disponível em: http://afolhadogragoata.blogspot.com/2012/12/ renato-lessa-filosofia-politica-para-que.html. Acesso em: 7 fev. 2019.

2 Disponível em: http://rlajt.com. Acesso em: 7 fev. 2019.

3 Disponível em: https:/www.ohchr.org/Documents/Publications/ HR-PUB-13-05.pdf. Acesso em: 7 fev. 2019.
}

Em uma definição sintética, o ICTJ estabelece que justiça de transição é

a maneira como países advindos de períodos de conflito ou repressão abordam violações aos direitos humanos em larga escala ou sistemáticas tão numerosas ou sérias que o sistema regular de justiça não será capaz de prover uma resposta adequada"'s.

A partir desse diagnóstico, são prognosticadas várias soluções que se integram no esforço de permitir a superação do passado de violações.

\begin{abstract}
A Justiça Transicional é um ramo altamente complexo de estudo, que reúne profissionais das mais variadas áreas, passando pelo Direito, Ciência Política, Sociologia e História, entre outras, com vistas a verificar quais processos de Justiça foram levados a cabo pelo conjunto dos poderes dos Estados nacionais, pela sociedade civil e por organismos internacionais para que, após o Estado de Exceção, a normalidade democrática pudesse se consolidar. Mais importante, porém, é a dimensão prospectiva desses estudos, cuja aplicação em políticas públicas de educação e justiça serve para trabalhar socialmente os valores democráticos, com vistas à incorporação pedagógica da experiência de rompimento da ordem constitucional legítima de forma positiva na cultura nacional, transformando o sofrimento do período autoritário em um aprendizado para a não-repetição (BRASIL, 2009, p. 12).
\end{abstract}

Comissões da verdade, processos de busca e identificação de desaparecidos, políticas de reparação material, simbólica ou psíquica, construção de sítios de memória, programas educativos além do julgamento penal de responsáveis por graves e sistemáticas violações aos direitos humanos são apenas algumas das faces mais aparentes dessa teia que forma o conceito de justiça transicional. Enquanto estabelecem a democracia liberal como horizonte normativo a ser alcançado, frequentemente as reflexões no campo da justiça de transição - como ocorria no caso anterior da transitologia - pecam em observar a substância de certos arranjos sociais e políticos fundados na violência, sedimentadas em camadas temporais diferentes.

\footnotetext{
${ }^{4}$ Disponível em: https://www.ictj.org/about/transitional-justice. Acesso em: 7 fev. 2019.
} 
Para usar o caso brasileiro, a compreensão de como operavam as instituições repressivas no contexto da ditadura militar de 1964-1985 é insuficiente para entender de que maneira seguiram se articulando formas, justificativas e práticas de violência das camadas dominantes da sociedade em direção às dominadas. É como se cada regime, cada momento político articulasse novas formas de violência que, no entanto, não deixam de se edificar sobre um longo acúmulo de práticas violentas nesse território. Ao remeter a um passado imediato, baseando-se na polaridade ditadura $v s$. democracia, as políticas e reflexões no campo da justiça transicional são incapazes de reconhecer em que medida cada forma de violência do período ditatorial diz respeito apenas àquele momento. Em um país periférico e de longa colonização, com vigência ainda mais longa do instituto da escravidão, é fundamental compreender como e em que medida exata os discursos e práticas de violência atualizam heranças do passado. Quais são as inovações trazidas em cada etapa histórica e quais são os caminhos de passagem garantidos a estruturas seculares de exercício da violência.

A partir desta interrogação, este trabalho pretende investigar os discursos assentados em uma perspectiva militarista da sociedade brasileira em dois contextos históricos: no âmbito da própria transição, na década de 1980 , e frente a um dos mecanismos consagrados pela justiça transicional, a Comissão Nacional da Verdade. Nos dois momentos serão buscadas as justificativas, as narrativas sobre o passado, sobre o conteúdo das disputas políticas por eles vividas e, especialmente, os caminhos de legitimação da violência por eles empregada. Tal esforço se concentrará na tensão entre ordem e exceção, mais do que na reflexão sobre legalidade ou ilegalidade, que tende a marcar as perspectivas mais formalistas em torno do emprego da violência de Estado. Com isso pretendemos contribuir para a compreensão dos mecanismos de justificação da violência no passado e no presente, permitindo encontrar os argumentos empregados e, a partir de então, enfrentar um dos elementos que permitem a atualização dessa violência em nosso arranjo social e político.

Nesse quadro, é preciso recorrer à afirmação de Zaffaroni (2012) sobre a incontornável produção de discursos justificadores para a violência do Estado. Se a violência é um elemento central da reprodução da ordem no Brasil, ela não pode ser operada apenas nas suas manifestações mais evidentes. Se a cada dia agentes do Estado abrem fogo contra seus cidadãos, é porque existem as condições para que isso aconteça, tanto no plano material quanto no simbólico.
Assim como a realidade material, os conceitos são reproduzidos a cada dia, preservando certos significados construídos ao longo do tempo, agregando novos à sua composição e deixando de lado os que não fazem mais sentido para os atores sociais e políticos que os mobilizam 5 . Dessa forma, é possível afirmar que, tanto no plano material quanto no simbólico, o lugar da violência precisa ser reconstruído a cada dia em nossa sociedade, integrando-se às atualizações da própria noção de ordem que se fazem em cada período histórico. Isso não significa negar seu longo processo de construção e as marcas que obteve do passado, mas sim afirmar que mesmo tais marcas persistem em um quadro em que encontram lugar para acomodar-se na realidade em permanente transformação.

Para cumprir esta proposta, o trabalho se dividirá em quatro seções que analisarão, respectivamente: (1) a noção de ordem e sua relação com a violência no Brasil; (2) a Doutrina de Segurança Nacional, como um ponto de sistematização dessa noção de ordem, sustentada a partir de então pelos militares; (3) os discursos mobilizados na Assembleia Nacional Constituinte de 1987-1988 em defesa de uma perspectiva militarizada do Estado, firmando uma compreensão do passado recente que se manteria ativa na Nova República; e (4) os discursos enunciados por militares ou agentes do Estado no âmbito da Comissão Nacional da Verdade.

\section{Ordem e violência no Brasil}

O histórico de intervenções militares na vida pública brasileira se confunde com a própria história republicana do País. Em sua maioria, as intervenções foram acompanhadas de discursos saneadores, que reivindicam um papel especial para as corporações militares na tutela da política nacional.

De maneira resumida, o argumento é que tanto o povo quanto as elites políticas são incapazes de dirigir o País de acordo com as suas características e o seu destino natural. Essa perspectiva se difunde entre os setores dominantes do Exército Brasileiro na medida em que se aprofunda a percepção de que a evolução

\footnotetext{
5 A definição dos conceitos como estruturas que comportam diferentes camadas de significados parte das reflexões do historiador alemão Reinhart Koselleck (2006). Segundo o autor, os conceitos sociais e políticos são polissêmicos, constituindo campo fundamental da disputa política. Nesse sentido, são investidos, em cada momento histórico, de significados diferentes, a depender do ator que os mobiliza. Esses significados são como camadas, que têm diferentes durações no tempo. O objeto do historiador dos conceitos é, portanto, a compreensão de quais camadas de significado operam em um mesmo conceito nos diferentes momentos históricos.
} 
nacional não atinge os parâmetros que consideravam ideais em função do predomínio dos privilegiados pelo berço (casacas) e pelas deficiências inerentes à constituição do povo, como a pouca disposição para o trabalho ou a frouxidão moral.

De acordo com Celso Castro (2008), ao longo do século XX os militares brasileiros constituíram o que chama de utopia autoritária, segundo a qual uma sociedade bem organizada seria formada pela transposição dos valores militares para o conjunto do País, especialmente a disciplina e a hierarquia. No limite, tal utopia pressupõe a extinção da política, atividade marcada necessariamente pelo dissenso e pela disputa de diferentes visões de mundo.

Em torno desse discurso se mobilizaram os militares brasileiros em diversos movimentos sobre o poder civil. A complexidade dos registros temporais mobilizados nesses movimentos reside em uma combinação particular do sentido evolutivo evocado para o País pelos militares, que como toda utopia projeta um futuro diferente - a evolução que deveria ocorrer, por oposição ao imobilismo do presente -, com a defesa da ordem, cujo conteúdo é sempre depreendido de alguma leitura da tradição, da reivindicação de valores permanentes.

Tendo em vista que, de acordo com Ansaldi e Giordano (2014), a violência na América Latina tem como vítimas prioritárias os grupos sociais desprovidos de recursos materiais e simbólicos de poder, cabe pensar em como, no Brasil, o exercício da violência em todas as suas dimensões se articula com a noção de ordem. Essa ideia, segundo Tales Ab'Sàber (2015), opera de maneira muito própria no Brasil.

Existe no Brasil uma ideia muito própria de ordem. Essa noção, vaga mas ativa; indefinida, mas muito afirmativa, é usada em momentos estratégicos por homens de Estado e está presente no horizonte do discurso conservador nacional e na sustentação das ações policiais mais duras, em geral de impacto social muito violento. No estranho lema ordem e progresso brasileiro, o peso autoritário e fantasmagórico da noção de ordem vem sempre primeiro (AB'SÀBER, 2015, p. 97).

Essa concepção de ordem que existe no Brasil, ainda segundo o mesmo autor, difere do sentido atribuído à lei, "entendida como alguma norma racional pactuada política e socialmente por um povo e uma nação" (AB'SÀBER, 2015, p.97). Ele afirma que, embora o Brasil subscreva uma concepção pretensamente universal de direitos, relativa ao desenvolvimento histórico dos países ocidentais, a reivindicação por ordem se dá para além das próprias estruturas legais. Ela deve ser compreendida a partir de uma longa trajetória de formação do nosso capitalismo periférico, marcado pelo latifúndio, pela centralidade da escravidão e de uma tradição autoritária de organização do poder político. Nesse quadro, Ab'Sàber traça uma espécie de genealogia das figuras que garantiram a ordem historicamente no Brasil, partindo dos "capitães de assalto" da colônia até os policiais na atualidade, passando pelos soldados amarelos, delegados varguistas do Estado Novo ou pelos membros da escuderia Le Cocq durante a ditadura militar.

Em argumento análogo, Vera Malaguti Batista $(2015$, p. 96) também chama atenção para a relação entre violência e ordem no Brasil, ressaltando "nossas fantasias e nossas alegorias de controle total de matrizes inquisitoriais ibéricas". A autora combina a análise das características ibéricas que historicamente marcaram nossa formação social e política com as perspectivas recentes sobre a gestão penal da pobreza nos marcos do neoliberalismo, desenvolvidas por Loic Wacquant. $\mathrm{O}$ resultado desse encontro de aportes do passado e do presente se manifesta na demanda permanente pelo emprego da violência como fiadora da ordem. Diante desse quadro, a própria noção de ordem se confunde com a reprodução continuada da violência, destinada a disciplinar ou eliminar quaisquer potências ameaçadoras que eventualmente se encontrem fora dos círculos privilegiados do poder econômico e político. A violência que observamos cotidianamente não pode ser compreendida, portanto, como uma anomalia da ordem, como uma disfuncionalidade. Não é a incapacidade do Estado brasileiro em completar seu longo e sempre inacabado processo de modernização que nos lega o uso corrente da violência. É, pelo contrário, o papel jogado pela violência como fundadora e, ao longo do tempo, garantidora da ordem que permite a reprodução de casos como os investigados nos estudos de justiça transicional, uma exigência da concepção "vaga, mas ativa" de ordem descrita por Ab'Sàber (2015), que sempre localiza inimigos e demanda seu enfrentamento para além dos diplomas legais.

A construção dessa noção de ordem, ainda que breve, deixa um alerta contra a tentação de remeter ao regime autoritário imediatamente anterior (1964-1985) a responsabilidade por todas as formas de exercício da violência que seguem vigentes até os dias atuais. A manutenção da arquitetura institucional desenhada na última ditadura é apenas um dos elementos - embora 
em nada desprezível - que explicam a persistência da violência e a sua reprodução em nosso cotidiano.

Observe-se aqui um ponto relevante: a ditadura não inventou a tortura e as execuções extrajudiciais ou a ideia de que vivemos uma guerra contra inimigos internos. Tais práticas perversas e as correspondentes concepções, racistas e autoritárias, têm a idade das instituições policiais no Brasil e, até mesmo antes de sua criação, já tinham curso. A ditadura militar e civil de 1964 simplesmente reorganizou os aparatos policiais, intensificou sua tradicional violência, autorizando-a e a adestrando, e expandiu o espectro de sua abrangência, que passou a incluir militantes de classe média. Ainda assim, foi esse regime que instituiu o modelo atualmente em vigência (SOARES, 2015, p. 25).

Frente a uma recente onda de estudos ${ }^{6}$ que mapeiam as continuidades autoritárias observáveis no presente, a ressalva de Luiz Eduardo Soares em relação à maneira como olhamos para o passado imediato pode servir como um chamado para que se encontre uma boa medida entre elementos que teríamos "recebido" da última ditadura e traços mais permanentes de nossa formação social que, como visto acima, funda a sua noção de ordem no emprego continuado da violência. A esperança de que o processo de democratização política em curso nos anos 1980 produzisse efeitos sobre as formas de exercício da violência por parte do Estado pode ter causado perplexidade em atores políticos, sociais e pesquisadores, quando a realidade foi confirmando a reprodução e a atualização dos padrões violentos verificáveis na ditadura e, pior do que isso, um crescimento em todos os indicadores relativos à violência estatal. Batista (2015) afirma que na saída da ditadura observava-se uma resistência à brutalidade policial na sociedade brasileira, mas esse panorama se converteu rapidamente na naturalização da truculência contra as parcelas mais pobres da população e daí ao seu aplauso. Ela identifica que, com enorme contribuição da mídia, o inimigo interno foi deslocado para o criminoso comum, particularmente os traficantes de drogas que operam no varejo, de perfil mais pobre. Assim, foi mantida a estrutura de controle social do período anterior e os níveis de autori-

\footnotetext{
${ }^{6}$ Os aniversários do golpe militar de 1964 têm sido particularmente marcados por publicações que fazem o balanço dessas continuidades, como Ecos do Golpe (IASI, 2014), O que resta da ditadura (SAFATLE, 2010), dossiês em periódicos, entre outras manifestações.
}

tarismo foram aprofundados em certos aspectos (BATISTA, 2008).

De acordo com Karam (2015), a militarização da segurança pública não corresponde apenas à vinculação das polícias militares ao Exército, mas inscreve-se também em um movimento internacional impulsionado pelos Estados Unidos a partir do governo Nixon, nos anos 1970, quando a temática da guerra às drogas começa a ganhar centralidade na agenda do País. A partir da proibição aleatória a certas drogas, os estadunidenses passaram a desenvolver uma política que implicou em significativa militarização ideológica da segurança pública, que tratava o combate aos produtores, comerciantes e consumidores de drogas sob a lógica da guerra. A difusão deste paradigma, a partir de sua centralidade na agenda americana, implicou a internacionalização de recursos financeiros, humanos e tecnológicos. A autora menciona as semelhanças entre forças especiais das polícias civil (CORE) ${ }^{7}$ e militar $(\mathrm{BOPE})^{8}$ no Rio de Janeiro, e as suas correlatas civis americanas (SWATs) ${ }^{9}$, para sustentar a ideia de que o militarismo não depende necessariamente do caráter exclusivamente militar da instituição (KARAM, 2015, p.35). Partindo destes aportes, percebe-se que o problema da violência na atualidade, entendido em relação à noção de ordem, é composto por muitas dimensões, que passam pela tradição ibérica de nossa formação social, pelas formas de organização do Estado concebidas na última ditadura militar e pela inscrição periférica do País no sistema internacional, que o torna terreno fértil para a incorporação da guerra às drogas como tema central da agenda política, com a consequente importação de técnicas, estratégias de combate e, obviamente, os discursos sobre o tema. Nesse sentido, o problema da violência deve ser apreendido em sua complexidade, envolvendo os diversos atores que jogam algum papel em sua recorrência.

Tal exercício é importante para compreender a legitimação das continuidades em relação ao período autoritário para além de uma explicação puramente inercial, que as observa como se fossem elementos intocados, esquecidos.

Partimos do pressuposto de que não há "restos", como se fossem aspectos não superados de uma forma que foi suplantada e deixou atrás de si

\footnotetext{
Coordenadoria de Recursos Especiais da Polícia Civil do Rio de Janeiro

8 Batalhão de Operações Especiais da Polícia Militar do Rio de Janeiro

9 Special Weapons and Tatics Teams dos departamentos de polícia civil nos Estados Unidos.
} 
elementos ainda esperando por serem enfrentados. Há permanências somente no sentido de que tais aspectos seguem funcionais à ordem a qual se associam (IASI, 2014, p. 81).

O que a passagem de Iasi busca salientar é a noção de que não existem enclaves esquecidos da antiga ordem na nova, mas sim elementos de continuidade que são constantemente produzidos e reproduzidos. $\mathrm{O}$ esforço desse texto corrobora tal ideia, na medida em que mostra um campo de disputa no qual os atores se engajaram ativamente para garantir a produção e reprodução de suas concepções.

\section{Organizando a exceção: a Doutrina de Segurança Nacional}

A noção de ordem, discutida no tópico anterior, foi fundamental para a construção da Doutrina de Segurança Nacional (DSN), que somou esse acúmulo às discussões formuladas nos meios militares ocidentais, através de teóricos e profissionais franceses e americanos. Tal doutrina trouxe a possibilidade de sistematização de alguns dos pontos que Áb Saber (ano) aborda como "vagos, mas ativos" na operação da ideia de ordem. As consequências dessa sistematização são observadas para além do plano discursivo, chegando ao arcabouço legal constituído pelo regime militar 19641985 bem como à própria configuração institucional do Estado brasileiro a partir de então.

A organização legal das instituições de segurança do Estado durante a ditadura militar foi depreendida da constatação de que o País se encontrava em estado de guerra. A prioridade conferida à ideia de segurança nacional integrava as instituições responsáveis pela segurança dos cidadãos em uma lógica de combate aos inimigos da nação, que podiam ser encontrados tanto interna quanto externamente. $O$ sentido mais geral dessa ideia promoveu uma militarização progressiva de diversos setores do Estado, desde instituições de segurança até órgãos econômicos, empresas estatais e outros. A partir de então, o Estado como um todo é organizado de maneira a pensar como cada aspecto de seu funcionamento incide positiva ou negativamente sobre a situação de segurança do País. Por causa disso, diversos militares passam a comandar órgãos que em outros tempos não eram considerados diretamente relacionados à segurança.

[...] não era a existência de um grande exército com todos os seus acessórios que se fazia fundamental à compreensão do militarismo, mas a subordinação de todos os outros aspectos [da vida] aos de caráter militar e a dominação da vida civil por idéias e valores militares (STERNTHAL apud BERGHAHN, 1981, 37). Franz Carl Endres, correspondente de assuntos militares do Frankfurter Zeitung chegou a definir "militarismo como o "estado mental" dos não-militares" (ENDRES apud BERGHAHN, 1981, 37). Um país, diria em outro lugar, pode ter um exército extraordinariamente forte e não ser militarista tanto quanto pode haver militarismo mesmo na ausência de um exército forte, como na Alemanha de Weimar. A chave do problema está num abrangente "espírito do uniforme" (ENDRES, 37) (TADDEI, 2008, p. 68).

O avanço do militarismo, observado no período da ditadura militar e amparado na doutrina de segurança nacional, foi elemento decisivo nos debates entre conservadores e progressistas no âmbito da Assembleia Nacional Constituinte. Grande parte das discussões no campo das instituições de segurança e mecanismos de defesa do Estado concentraram-se na disputa entre a preservação do militarismo ou sua contenção. Daí decorre a importância de voltar e compreender minimamente as condições nas quais se construiu a institucionalidade vigente no regime militar.

A ditadura emergiu em um momento de bipolarização do mundo, no qual o Brasil pretende se inscrever como parte do chamado mundo livre, o que necessariamente o ligava - ainda que formalmente - a um conjunto de instituições centradas em torno da defesa dos direitos civis e políticos. Em outras palavras, a repressão política foi articulada, em termos ideológicos, durante a ditadura militar, como um mal excepcional e passageiro que, por força das circunstâncias, deveria se sobrepor aos princípios constitucionais. Cabe lembrar aqui a noção de duplicidade do Estado, desenvolvida por diversos autores e presente na obra da antropóloga Rita Segato (2014). Essa noção afirma que a atuação estatal inescapavelmente tem uma dimensão não legal que convive com os marcos de sua legalidade. Essa dimensão seria mais facilmente observável em ordens autoritárias, como a que analisamos aqui, mas não deixaria de existir em outras formas estatais. A duplicidade da ação estatal, teorizada desde o nazismo por Ernst Frankel e relida por Agamben através de Schmmitt e Benjamin, diz respeito a uma inevitável convivência entre a regra e a exceção (SEGATO, 2014, p.52). A duplicidade diz respeito ao fato de que determinadas zonas de atuação do Estado nunca 
podem estar completamente submetidas aos diplomas legais que, em teoria, regulam qualquer forma de ação estatal. Um exemplo é a atuação de policiais nas ruas, que frequentemente estão investidos do poder discricionário que não está orientado pelas balizas estabelecidas pelas leis. Um policial que decide matar um suspeito emitiu um julgamento sumário baseado em sua avaliação da situação concreta, que podia ou não envolver algum risco para si ou para os demais em volta. Essa ação, apesar de não legal, não envolve as consequências previstas para um ato ilegal, confirmando a hipótese de que a atuação do Estado exige essa duplicidade que envolve a existência de zonas intermediárias entre o legal e o ilegal, onde uma série de práticas são consideradas normais, embora não sejam exatamente legais.

Apesar de formulada por um governo autoritário, instituído através de um golpe de Estado, a Constituição de 1967, aprovada pela Câmara dos Deputados em 24 de janeiro, não é um documento extremamente restritivo, do ponto de vista dos direitos individuais. As mudanças promovidas no texto constitucional em 1969 evidenciam o recrudescimento das atividades repressivas do Estado, que se arma de mecanismos legais que legitimem sua ação, bem como toma providências para alcançar uma configuração institucional que facilite seus processos.

Ainda que, num primeiro momento, possamos admitir que essa intricada estrutura foi se definindo de forma reativa, o que se verificou ao fim de muito pouco tempo foi a instalação de um sofisticado sistema de segurança e controle inconstitucionalmente consolidado, cujas características não podem jamais ser atribuídas a situações circunstanciais. O "sistema", a comunidade de informações fazem parte de um bem articulado plano que procurou não só controlar a oposição armada mas também controlar e direcionar a própria sociedade (D'ARAUJO; CASTRO; SOARES, 1994, p. 18).

Consolida-se, com isso, a ideia de que se vive uma guerra interna, o que contribui em boa parte para explicar a contradição entre o discurso da normalidade democrática e do estado de direito e a prática repressiva. Na realidade, ao alterar apenas os artigos relativos à operacionalização da justiça e manter inalterados os princípios e garantias individuais, o regime sinalizava que a vida seguia "normal" para os cidadãos "normais", restando as normas de exceção apenas para os "inimigos". Baseado nas reflexões de Agamben sobre o que constitui o poder soberano - a capacidade de decidir sobre a exceção -, Safatle e Teles (2013) lembram que a ditadura brasileira foi marcada pelo esforço de preservação da legalidade, mas que frequentemente

a lei era suspensa. Uma ditadura que se servia da legalidade para transformar seu poder soberano de suspender a lei, de designar terroristas, de assassinar opositores em um arbítrio absolutamente traumático. Pois neste tipo de situação nunca se sabe quando se está fora da lei, já que o próprio poder faz questão de mostrar que pode embaralhar, a qualquer momento, direito e ausência de direito (SAFATLE; TELES, 2013, p. 11).

Essa sinalização é compatível com os postulados da Doutrina de Segurança Nacional (DSN), difundida no Brasil a partir dos anos 1950. A difusão da doutrina de segurança nacional no Brasil remete à participação dos militares brasileiros na Segunda Guerra Mundial. A aproximação de lideranças da Força Expedicionária Brasileira com oficiais das Forças Armadas dos Estados Unidos ensejou um ambiente cooperativo que transcenderia o esforço de guerra. Os acordos de cooperação militar e modernização das armas brasileiras, firmados por Getúlio Vargas, contribuiriam para manter abertos os canais de comunicação entre os oficiais dos dois países. Foi através dos americanos que os oficiais brasileiros se aprofundaram no desenvolvimento de suas concepções de segurança nacional - muito caras aos franceses envolvidos na repressão dos movimentos anticoloniais da década de 1950 (BAUER, 2011). Nesse contexto, em 1949 foi criada através da Lei no 785/1949 a Escola Superior de Guerra (ESG), inspirada no modelo americano da National War College e localizada na Fortaleza de São João, no Rio de Janeiro.

Os intercâmbios que resultaram na difusão da DSN se deram também através de cursos realizados por oficiais brasileiros nos Estados Unidos, além dos treinamentos oferecidos na Escola das Américas, localizada no Panamá. Esse centro de formação militar e difusão ideológica das Forças Armadas dos Estados Unidos recebeu, pelo menos a partir de 1954, uma série de brasileiros que ocupariam posição de destaque no regime militar de 1964. A lista de graduados brasileiros na escola inclui agentes dos mais variados postos e setores das armas brasileiras. Desde membros da polícia do exército até agentes de contrainformação, 
passando por operadores de rádio, instrutores, oficiais de operações em selva e assim por diante ${ }^{10}$.

Nesses centros de pensamento militar, o combate ao comunismo assumiu progressivamente o topo da pauta de prioridades e a ideia flexível de um inimigo difuso começou a tomar forma. Durante todo o período democrático 1946-1964, a doutrina de segurança nacional foi difundida nos meios militares e amadurecida nos altos escalões das Forças Armadas.

Alguns dos "intelectuais" militares, como Golbery do Couto e Silva, pretenderam formalizá-la segundo critérios acadêmicos de cientificidade, conferindo um selo de legitimidade. Além das formações de oficiais brasileiros na Escola das Américas ou em outros espaços de intercâmbio com militares americanos, a literatura militar francesa que embasou a DSN teve ampla repercussão nos meios militares brasileiros. Foi o caso dos livros de Bonnet, Guerrilhas e Revoluções, lançado pela editora Civilização Brasileira em 1963, e de Galula, Teoria e prática da contrarrebelião, editado pela GRD em 1966. No Brasil, o prefácio de Carlos de Meira Matos ao livro de Bonnet e o livro Geopolítica do Brasil, lançado em 1966 por Golbery do Couto e Silva, contribuíram para promover o debate sobre a teoria da guerra revolucionária, que foi decisiva na formalização da DSN. Com a doutrina de segurança nacional, o conceito de ameaça é ressignificado, de maneira a compreender também movimentos internos.

$\mathrm{Na}$ base desse pensamento encontra-se a premissa de que o comunismo, em seu caráter internacionalista, representa um inimigo capaz de infiltrar-se no seio de sociedades que não lhe são familiares e promover a sua corrupção. É de se reparar que o comunismo não é apresentado no plano do pensamento, mas sim como um "lado" de uma guerra. Ele é materializado como um inimigo, que tem uma organização central, um comando e atende a um propósito definido. Nesse sentido, aqueles que o defendem seriam agentes dessa arquitetura maior.

Esse ethos persecutório não se traduzia num programa de ação político-administrativo, fundando-se, tão-somente, no anseio de "eliminar o inimigo", visto como subversivo interessado na implantação

\footnotetext{
${ }^{10}$ A lista de graduados brasileiros na Escola das Américas entre 1954 e 1996 está disponível em: http://www.derechos. org/soa/br5496.html. Acesso em: 20 fev. 2013. Há também uma lista de figuras notáveis do Brasil que passaram pelo centro de treinamento. Disponível em: http://www.derechos.org/soa/br5496. html. Acesso em: 20 fev. 2013.
}

de uma "república sindicalista" contrária aos "valores morais da democracia ocidental". Esse jargão - de forte conotação ético-moral, tendente a identificar a origem dos problemas tanto nas pretensões "subversivas" quanto numa difusa "crise moral" - provinha de consolidada cultura política de direita, por isso mesmo anticomunista, inspirada em certa liderança civil. [...] Seus atos indicavam que ele supunha ser possível governar dentro dos limites da lei, depois afastados da vida pública alguns "elementos que a perturbavam" (FICO, 2001, p. 37-39).

Outro ponto fundamental que também aparece na passagem é a afirmação que a doutrina da segurança nacional faz, por oposição, acerca da identidade brasileira. Ao afirmar o comunismo como "ideologia exógena", delimita-se o espaço no qual se constrói a identidade nacional, sempre associada com os valores ocidentais e particularmente ligada ao cristianismo. Trata-se de uma concepção de identidade que exclui em grande parte a diversidade de narrativas e autopercepções que podem ser encontradas no Brasil. Esse modo de pensar relaciona-se com os pontos centrais deste texto. Nesse sentido, tudo o que destoava de um ideal bastante rígido de vida era considerado risco de degradação moral, convertida em ameaça à segurança coletiva. A conversão da disputa política e social em questão moral empurra a divergência para fora dos limites considerados aceitáveis, transformando-a em ameaça à ordem. No caso particular da DSN, a afirmação dos chamados valores ocidentais vem sempre associada à rejeição do comunismo, o que não seria o caso mais adiante. Ainda assim, permanece, em todos os casos, a necessidade de predizer um modelo de conduta como elemento determinante para a segurança do Estado e da sociedade (COIMBRA, 2000).

$\mathrm{O}$ elemento de maior impacto trazido por essa virada política e teórica é, porém, a identificação de que o País se encontra em estado de guerra. E com um agravante. É uma guerra permanente e contra um inimigo não evidente, disfarçado e traiçoeiro. Nesse cenário, arma-se um pano de fundo conceitual que legitima a destituição da cidadania para a parcela da população tida como inimiga disfarçada na guerra que se travava. A noção de guerra é fundamental na cultura militar, diferenciando-a do mundo civil. Segundo Celso Castro (2009), o primeiro elemento na construção da identidade de um militar é a oposição ao que chamam de "mundo civil". 
Tornar-se militar significa, acima de tudo, deixar de ser civil. A oposição entre civis e militares é estruturante da identidade militar. Ao ingressar numa academia militar, o jovem é submetido a um processo de construção da identidade militar que pressupõe e exige a desconstrução de sua identidade "civil" anterior. Mesmo quando transita pelo assim chamado "mundo civil", o militar não deixa de ser militar - pode, no máximo, estar vestido à paisana. [...] Para qualquer militar, porém, ser "militar" necessariamente aparece entre os primeiros atributos, se não como o primeiro. Isso se deve ao fato de fazerem parte de uma instituição que chamei, em outro texto, de "totalizante", para diferenciar de "instituição total" estudada por Erving Goffman (CASTRO, 2009, p. 24).

Se determinadas características que se observam no discurso dos militares envolvidos com a repressão são constituintes da própria identidade militar, quase independentemente do tempo histórico, outras têm relação direta com o contexto de hegemonia da DSN e das teorias sobre guerra revolucionária nesses meios. Apesar de articularem uma visão de mundo que parte da dicotomia civil-militar, os militares brasileiros que arquitetaram e operaram o regime 1964-1985 procederam a uma "militarização" de setores civis da sociedade. A diferenciação entre militares e civis, que do ponto de vista dos primeiros os coloca em patamar superior aos últimos, também opera no sentido de resguardar o mundo civil das noções de honra e sacrifício próprias a um combatente militar. Entretanto, a partir da DSN os militares deixam de tratar como civis um conjunto de cidadãos identificados como inimigos internos. A partir dessa lógica, deixam de reconhecer a essas pessoas os direitos que lhes competiam como cidadãos nacionais. A ideia de que o inimigo interno é apenas uma ponta de um sistema internacional complexo, destinado a promover a desestabilização da ordem, faz com que seus "agentes" sejam percebidos pelos militares como combatentes, dispostos, portanto, a aceitar o tipo particular de moral que prevalece em tempos de guerra.

Os chamados subversivos não são apenas criminosos, são prisioneiros de guerra e, como tal, não devem ter o direito de reivindicar um tratamento compatível com o oferecido a um cidadão brasileiro, protegido pelas garantias individuais asseguradas na Constituição. Dessa maneira, a doutrina de segurança nacional se acomoda ao treinamento militar, que investe no endurecimento dos homens dispostos ao sacrifício em tempos de guerra. Esse sacrifício deve se dar em todas as dimensões, desde a disposição para a morte em nome da pátria até à disposição para o sacrifício das conviç̧ões morais e dos sentimentos de humanidade em relação ao outro, o inimigo. $\mathrm{O}$ senso do dever certamente é um componente importante para a explicação das práticas e costumes autoritários consolidados dentre os agentes de segurança pública durante o período 1964-1985. Essa lógica, analisada por diversos pesquisadores - como Bauer (2011), Fico (2007), Coimbra (2000), Cardia (1995) ou D'araujo, Castro e Soares (1994), que se debruçaram sobre a DSN - foi reconhecida por parcelas do Estado brasileiro, como a Comissão Especial sobre Mortos e Desaparecidos Políticos, formada em 1995 e que em seu relatório afirma o seguinte:

A Doutrina de Segurança Nacional, idealizada em grande parte por Golbery, foi uma tentativa de fundamentar conceitualmente a suspensão das garantias constitucionais, a limitação das liberdades individuais, a introdução da censura aos meios de comunicação e a repressão total aos que se opunham por meio de atividades clandestinas. A defesa do cristianismo ocidental foi usada como pretensa inspiração dessa doutrina, o que sempre foi contestado pela Conferência Nacional dos Bispos do Brasil (CNBB), por expoentes como Dom Cândido Padim e padre Joseph Comblin, ambos igualmente vítimas de investigações e processos por parte do regime. [...] Diferentes conceituações de guerra guerra psicológica adversa, guerra interna, guerra subversiva - foram utilizadas para a submissão dos presos políticos a julgamentos pela Justiça Militar. Assim, já no final de 1969, estava caracterizada a instalação de um aparelho de repressão que assumiu características de verdadeiro poder paralelo ao Estado no país. Seus agentes podiam utilizar os métodos mais sórdidos, mas contavam com o manto protetor representado pelo AI-5 e pela autoridade absoluta dos mandatários militares, incluindo-se aí a suspensão do direito de habeas-corpus, a formalização de decretos secretos e a edição de uma terceira Lei de Segurança Nacional (DL 898), introduzindo prisão perpétua e até mesmo a pena de morte para opositores envolvidos em ações armadas que tivessem causado morte (DIREITO À MEMÓRIA E À VERDADE, 2007, p. 23).

Para levar adiante esse esforço de guerra, empreendido a partir das consequências derivadas 
da doutrina de segurança nacional, foram criados organismos de informação e de repressão policial propriamente dita, em um complexo sistema de identificação e combate ao inimigo difuso. Além de criar novas instituições, o Exército investiu no controle e reconfiguração de algumas das que já existiam. Os vinte e um anos de regime autoritário são marcados por um estrito controle do exército sobre todas as instituições responsáveis pela segurança pública. Esse seria o ponto central para a defesa de uma perspectiva militarista de Estado e sociedade no âmbito da constituinte de 1987-8. Se o regime militar se tornara indefensável na maioria dos seus aspectos, as formas de defesa da ordem requeriam atualizações.

\section{Transição - defesa do passado e do militarismo nos discursos da constituinte}

A ideia de que o País viveu um período de transição a partir de 1974 foi comum a atores sociais, políticos e analistas (LESSA, 1989; WERNECK, 1986; TEIXEIRA DA SILVA, 2000; e outros). Entretanto, os sentidos encontrados em meio ao emaranhado de eventos e mobilizações que ocorreram no período podem variar de acordo com as diversas perspectivas de análise. Embora a maior parte das leituras concorde que o elemento mais característico de processos de transição como o brasileiro é a incerteza, esquemas explicativos como o de O'Donnell e Schmitter (1988) reservam espaço reduzido para o protagonismo de atores que não se engajassem diretamente na relação (mesmo que crítica) com os grupos que ocupavam o Estado. A transitologia, campo de estudos que derivou dos trabalhos fundadores de O'Donnell e Schmitter, tendeu a observar com maior cuidado as divergências existentes no interior dos blocos de poder - através de categorias como brandos e duros, opositores minimalistas e maximalistas - e os impulsos liberalizantes ou democratizantes que predominavam em cada processo - adaptando categorias formuladas por Robert Dahl (1971) em Poliarquia. Menor ênfase recai sobre mobilizações que se dão na base da sociedade, como as greves do ABC paulista em 1978, os movimentos contra o aumento do custo de vida, também no fim dos anos 1970 , e as caravanas pela anistia, que buscavam trazer para o centro do debate público o tema dos perseguidos políticos ${ }^{11}$. Ao longo

\footnotetext{
${ }^{11}$ O processo de transição no Brasil foi resultado de um longo desgaste do regime militar instituído em 1964. Contribuíram para este desgaste elementos externos, como a reorientação da política
}

de todo o processo de transição, os esforços do governo (tanto Geisel quanto Figueiredo, posteriormente) se encaminharam no sentido de isolar estas mobilizações e escolher os interlocutores com os quais dialogariam, mantendo a transição em uma arena controlada pelo governo, na qual as instituições seguiriam funcionando em modo excludente e restritivo. $\mathrm{O}$ fortalecimento das entidades de representação profissional, como a Ordem dos Advogados do Brasil (OAB) ou a Associação Brasileira de Imprensa (ABI) e a pressão exercida pela imprensa alternativa, bem como por atores tradicionais (cujo exemplo mais destacado é a CNBB), constituíram elementos decisivos para que os temas da democracia e dos direitos humanos assumissem centralidade no debate público brasileiro do período.

Os destinos do processo de transição estiveram em disputa no decorrer da década de 1980, o que era reconhecido pelos próprios analistas do período. O diagnóstico de Werneck (1986) era o de que a realização de um processo de reforma institucional não representava necessariamente a superação do autoritarismo, na medida em que a transformação das instituições do País poderia se restringir a uma questão de forma, deixando em segundo plano o conteúdo das práticas e arranjos consagrados na modernização conservadora do Brasil. Nos países que encontraram sua via de transição através de uma ruptura com o regime anterior, o autoritarismo constituía um "outro político", com o qual era necessário romper para construir algo novo, diferentemente do caso brasileiro. Esse modelo de substituição do regime autoritário foi consagrado com a decisão de fazer uma constituinte não exclusiva, ou seja, uma assembleia constituinte composta pelos parlamentares eleitos nos últimos dois pleitos (1982 e 1986) - o que contrariou a maior parte das forças oposicionistas no País. Assim sendo, a Carta de 1988 nasceu dos trabalhos de duas legislaturas escolhidas ainda sob as regras eleitorais estabelecidas pelo governo militar. Embora as eleições legislativas de 1986 tenham renovado parte significativa do

exterior dos Estados Unidos a partir do governo Carter, e fatores internos, como as cada vez mais irrefutáveis denúncias de graves violações aos direitos humanos, achatamento salarial, desaceleração do crescimento, entre outros. A partir de então, diversos movimentos da sociedade civil se fortaleceram e pressionaram na direção da democracia. Associações de bairro e movimentos contra o aumento do custo de vida se somaram às iniciativas mais diretamente políticas, como a reivindicação por anistia, a pressão pelo fim do AI-5, do bipartidarismo e das eleições indiretas. Foi um momento de retomada de antigos movimentos e surgimento de muitos novos, no qual o protagonismo da sociedade civil foi decisivo para a derrubada do regime. Para tratamento mais detalhado do tema, ver, por exemplo, Perruso (2009), Em Busca do Novo: intelectuais brasileiros e movimentos populares nos anos 70/80. 
Congresso, alguns dos parlamentares foram escolhidos ainda em 1982. Para os fins deste trabalho, vale atentar de maneira mais cuidadosa para as discussões em torno das forças armadas do Estado, que resultaram nos artigos 142 e 144 da nova Carta. Essas discussões se processaram, sobretudo, na Subcomissão IV-B.

A Constituinte de 1987-1988, a exemplo de todo o processo de transição, reflete as ambiguidades do período, oferecendo sinais contraditórios aos analistas que se debruçam sobre o tema. Por um lado, é preciso destacar a importância das mobilizações na sociedade civil, empurrando as instituições na direção da superação da organização legal instituída pelo autoritarismo, em 1967. A própria realização de uma constituinte nasce de um impulso renovador, que se expressara em eventos emblemáticos como as Diretas Já! e as vitórias oposicionistas nos principais governos estaduais do País em 1982. Por outro lado, o caminho de uma constituinte parlamentar, com expressiva representação dos atores da antiga ordem, revela os entraves ainda existentes para sua superação. No curso dos trabalhos, esses sinais contraditórios seguiram sendo a tônica, resultando em um texto de espírito inegavelmente democratizante, mas ainda marcado por importantes enclaves autoritários.

A constituinte, subdividida em comissões e subcomissões, teve, portanto, diferentes campos de batalha, nos quais as possibilidades de pressão por parte da sociedade civil variaram. Enquanto algumas comissões foram verdadeiras arenas de debate público plural e diverso ${ }^{12}$, outras tiveram espaço reduzido para o dissenso e a produção de soluções legislativas inovadoras. Foi o caso da subcomissão IV-B, de onde foram retiradas as falas aqui analisadas.

A Subcomissão de Defesa do Estado, da Sociedade e de sua Segurança (IV-B) desenvolveu seus trabalhos entre os dias 7 de abril e 25 de maio de 1987, quando o texto foi encaminhado para a Comissão da Organização Eleitoral, Partidária e de Garantia das Instituições. É de se notar que a discussão sobre segurança pública ficou sob responsabilidade da Comissão de Garantia das Instituições e não sob a Comissão de Direitos e Garantias do Homem e da Mulher, revelando, desde já, em que termos se dariam as discussões. Logo no começo dos trabalhos se formou uma polarização entre o parlamentar petista, José Genoíno - às vezes

\footnotetext{
${ }^{12}$ Ver LOUBACK, Joyce. Os conceitos de igualdade, cidadania e democracia nos discursos do campo popular ao longo da Assembleia Constituinte de 1987-1988. 2016. Tese (Doutorado em sociologia) - Instituto de Estudos Sociais e Políticos, Universidade do Estado do Rio de Janeiro, Rio de Janeiro, 2016.
}

acompanhado dos pemedebistas Lysâneas Maciel e Iram Saraiva, e do pedetista César Maia e, já na comissão temática do comunista Haroldo Lima -, buscando mecanismos de limitação do poder do Estado, e o relator Ricardo Fiuza - sempre acompanhado por Ottomar Pinto, Arnaldo Martins, Asdrúbal Bentes e Sadie Hauache -, na defesa mais constante da preservação do espaço de atuação das instituições armadas, tal como foram configuradas no regime militar ${ }^{13}$. É possível reproduzir, no âmbito da Subcomissão, o argumento de Pilatti (2008) sobre a existência de um bloco progressista - que, embora minoritário usou todos os instrumentos possíveis para amplificar sua voz - e um bloco conservador, majoritário (especialmente no âmbito dessa subcomissão), que usava os caminhos existentes para preservar a ordem tal como ela era naquele momento, reduzindo sempre que possível os impulsos transformadores que chegavam à constituinte. A Subcomissão representa também um bom exemplo do que afirmou Lessa (1989) quando defendeu a ideia de que as elites da ordem anterior preservaram seu poder de veto em relação a agendas consideradas excessivamente ousadas ou transformadoras. Aqui, justamente no que dizia respeito ao coração do regime, que eram as forças de segurança e mecanismos de defesa do Estado, é possível observar como as ideias mais inovadoras foram sendo desmontadas e rejeitadas, uma por uma, até que se chegasse a um texto que reproduzia, em grande medida, a realidade já existente no País. Pode-se dizer que as disputas se resumiram em torno de uma clivagem entre militarismo e poder civil.

Todos os argumentos apresentados na elaboração do texto constitucional são atravessados por uma tensão que os próprios atores envolvidos reconheceram como estruturante daquele momento por eles vivido: militarismo $v s$. poder civil. Essa disputa marcou os trabalhos da Comissão IV e da Subcomissão IV-B, sendo a linha que separava os blocos conservador e progressista - seguindo a classificação de Pilatti. O título da constituição redigido nesses dois espaços dividiu-se em quatro eixos temáticos: dispositivos de defesa do Estado (estado de emergência e de sítio);

\footnotetext{
${ }^{13}$ Os autos da subcomissão IV-B foram objeto da tese de doutorado deste autor, onde se discute em maior detalhe os critérios de seleção para as audiências públicas, bem como o perfil dos atores mais relevantes nas discussões ali desenvolvidas. Para os fins deste artigo, foram selecionadas falas apenas dos parlamentares que compuseram a Comissão IV ou a Subcomissão IV-B, com destaque para aquelas do campo conservador, que buscava sedimentar no debate público um discurso em torno da necessidade da exceção (apesar dos lamentáveis excessos) na garantia da ordem, tema central de nossa discussão.
} 
forças armadas; segurança nacional e segurança pública. Os quatro eixos foram atravessados por debates em torno da extensão do poder militar e da militarização do exercício do poder do Estado. Os argumentos empregados pelo bloco conservador objetivavam, em linhas gerais, garantir os caminhos de passagem das antigas estruturas de segurança do Estado na nova ordem. Todas as posições do bloco tiveram em comum o fato de enunciarem a necessidade de que os militares tivessem mais competências e menos controles institucionais ou sociais civis.

A defesa do militarismo teve como aspectos fundamentais a valorização da tradição, da hierarquia e da disciplina. Se seu olhar para a história e, particularmente para a história recente do País, não trazia um sentido de exaltação, tampouco se pode afirmar que construíam sua narrativa sobre o passado partindo de uma perspectiva crítica. A todo momento afirmaram que as denúncias do que ocorrera na ditadura não podiam se converter em uma "fobia de militares" ou "medo do intervencionismo militar". Sustentavam que a constituição deveria ser escrita para as gerações futuras, desconsiderando traumas e ressentimentos em relação ao passado, mas, ao mesmo tempo, reivindicavam a tradição como argumento suficiente para garantir a permanência de estruturas institucionais desenhadas no regime anterior - como a garantia de exclusividade no policiamento ostensivo para as PMs.

No Brasil, o militar estaria de um lado, e o civil, do outro. Isso não é verdade. [...] Daí se chega a uma primeira conclusão, ou seja, a de que, hoje, no Brasil, os militares fazem uma chantagem: a da segurança interna baseada na doutrina de segurança nacional. Esta doutrina é, então, responsável por tudo que aconteceu nesses 20 anos de Governo. [...] Dizer que a doutrina da ESG é responsável pela ação dos DOICODIs, pela repressão feita aos grupos subversivos, que queriam implantar o terrorismo e a guerrilha rural e urbana neste País, é o mesmo que responsabilizar, repito, o cristianismo pelas torturas da Inquisição.

Estas são algumas considerações que eu desejava fazer, para deixar bem claro que essa conotação de militarismo, mesmo no regime passado, não existe (PINTO, 1987, comunicação verbal). ${ }^{14}$

É importante observar que os parlamentares do bloco conservador recusam a própria existência de uma

\footnotetext{
${ }^{14}$ Trecho de depoimento verbal de Ottomar Pinto, registrado em Ata da Subcomissão IV-B da Assembleia Nacional Constituinte, de 1 jun. 1987, na cidade de Brasília, DF, arquivada no Senado Federal.
}

dicotomia civil-militar. Os críticos do militarismo, por sua vez, colocaram, a todo momento, a necessidade de estabelecer o controle civil sobre as instituições militares. Em sua opinião, os textos aprovados na subcomissão e na comissão - muito parecidos entre si - se inscreviam em uma longa tradição de defesa do militarismo no Brasil. Para combater esta tradição seria necessário debater desde questões corporativas, como previdência e orçamento, até o estabelecimento de mecanismos de controle sobre as ações dos militares - como a determinação de que eles só podem intervir em questões de segurança interna caso convocados expressamente pelo presidente da república e a preservação de certas garantias individuais mesmo nos estados de defesa.

Devo dizer que a meu juízo este capítulo ou este relatório se insere na linha militarista. [...] O nobre Relator, Sr. Presidente, diz em determinado instante que nós devemos pensar menos no passado e mais no futuro. Mas não é essa a experiência brasileira, e não é essa a experiência dos povos. Os povos programam o futuro pensando no passado. Penso que nós devemos detectar no passado o que tem sido certos fatores de impedimento do desenvolvimento social, econômico e político no Brasil, e um dos pontos importantes é a questão do militarismo. Mas Forças Armadas não se identificam com militarismo. O militarismo é a corrente política que se aproveita da corporação militar para intervir na vida do país de forma despropositada, estabelecendo uma contradição, nobre Constituinte Ricardo Fiuza, que penso que V. Ex. ${ }^{\text {a }}$ não contribuiu com o seu relatório para superar a contradição entre o Estado e as Forças Armadas. [...] A doutrina de segurança nacional é a que nós conhecemos, com a qual, como V. Ex. ${ }^{a}$ diz no início, alguns são ressentidos. Eu, por exemplo, fui vítima dessa doutrina. Fui torturado por ela, fui preso, muita gente, companheiros nossos foram mortos por causa da doutrina de segurança nacional, tudo porque defenderam a Pátria brasileira, com força, com energia.[...] É isso que digo: depois de tanta luta, de tanto sofrimento, de tantas vicissitudes, foi para isso, foi para repetir o que escrevemos em 1934, sob uma concepção nítida, clara, explícita e reconhecidamente militarista? E estamos aqui nesta Constituinte para fazer tudo de novo, passar a limpo o quê? Passar a limpo a doutrina militarista da Constituição brasileira (LIMA, 1987, comunicação verbal) ${ }^{15}$.

\footnotetext{
${ }^{15}$ Trecho de depoimento verbal de Haroldo Lima, registrado em Ata da Subcomissão IV-B da Assembleia Nacional Constituinte, de 1 jun. 1987, na cidade de Brasília, DF, arquivada no Senado Federal.
} 
A fala de Haroldo Lima é fundamental no sentido de ilustrar a tensão que esteve colocada durante os trabalhos da Subcomissão IV-B e da Comissão IV entre um bloco minoritário que defendia a necessidade de limitar o poder militar e um bloco majoritário conservador que pretendia preservar as estruturas de segurança tal como elas existiam naquele momento.

As menções às graves violações aos direitos humanos ocorridas no período eram sempre trazidas por constituintes progressistas com o objetivo de alertar para o sentido geral do texto produzido na subcomissão ou na comissão. Aqui já não se tratava de preservar um ou outro dispositivo, mas de discutir as próprias razões da reunião de uma assembleia constituinte naquele momento e, a partir disso, o que se esperava dela como resultado final. Os exemplos do passado recente do País, principalmente quando mobilizados pelos parlamentares progressistas, almejavam formular uma crítica ao próprio espírito dos debates que transcorriam na subcomissão e na comissão temática. Já os constituintes do bloco conservador recorreram ao passado recente de diversas maneiras, desde o olhar lançado sobre os textos constitucionais de 1967 e 1969 até a lembrança de eventos como a crise que culminou na queda do presidente João Goulart ou o enfrentamento às esquerdas armadas dos anos 1960 e 1970. Se seu objetivo consistia na preservação do modelo de organização das instituições armadas do Estado, era preciso articular uma narrativa que justificasse os esforços repressivos empreendidos no período anterior, que resultaram nessa organização que se queria preservar.

A guerra revolucionária é uma guerra interna, intestina, que não pode ser tratada com luvas de pelica. Então, a repressão - não estamos aqui para fazer a apologia dessa repressão, nós absolutamente, não compartilhamos, nem participamos - foi direcionado contra segmentos nacionais idealistas, respeitáveis, e que entediam, por exemplo, que o terrorismo, o seqüestro, a guerrilha, eram as únicas formas possíveis de modificar a ordem constituída naquela época. Então, foi contra esses estamentos que o aparato de defesa do Estado se mobilizou (PINTO, 1987, comunicação verbal) ${ }^{16}$.

No Brasil, em 63/64, o presidente e o povo nas ruas, uma insatisfação social generalizada, a vontade

\footnotetext{
16 Trecho de depoimento verbal de Ottomar Pinto, registrado em Ata da Subcomissão IV-B da Assembleia Nacional Constituinte, de 23 abr. 1987, na cidade de Brasília, DF, arquivada no Senado Federal.
}

nacional - que foi dito aqui que é bastante firme - apontava a sua desaprovação àquele estado de coisas. As Forças Armadas ficaram nos quartéis e só em última instância é que houve aquele movimento que depois, infelizmente, se prolongou além do que costumeiramente ocorria. $\mathrm{E} \mathrm{V}$. Ex ${ }^{\mathrm{a}}$ sabe que a intenção do primeiro presidente da revolução era entregar, eu creio, o poder a um civil (PINTO, 1987, comunicação verbal $)^{17}$.

A justificação do golpe e da repressão política se dão por meio da lógica da guerra, apresentada no primeiro tópico do capítulo. Por essa razão, os parlamentares conservadores reafirmavam a necessidade do envolvimento militar na vida civil e a reorganização das instituições no curso da ditadura. As disputas em torno do passado recente foram fundamentais para delimitar a extensão das mudanças que seriam promovidas pelo novo texto constitucional. Aceitar a narrativa de que o regime militar fora um período de violência arbitrária contra a população civil representava, na perspectiva dos parlamentares do bloco conservador, reconhecer a necessidade de uma mudança radical nas estruturas então vigentes. Por isso, foi fundamental para eles reafirmar a ideia de que as violações aos direitos humanos foram apenas excessos, acidentes de percurso em uma guerra justamente empregada pelas forças armadas no País.

Sr. Presidente, é natural, desde o início, que imaginávamos que uma comissão ou uma subcomissão que tratasse da Defesa do Estado, da Sociedade e de sua Segurança, suscitasse imediatamente, numa época de grandes transformações na sociedade brasileira, alguns ressentimentos ou alguns sentimentos que, na realidade, devem ou deveriam ter sido esquecidos, quando da elaboração do trabalho. E por quê, Sr. Presidente? Porque estávamos e estamos saindo de um período autoritário, de um regime de exceção, onde as frustrações, as mágoas, as injustiças, que são sentimentos absolutamente legítimos, naturalmente, tendem a influir decisivamente no nosso comportamento na elaboração da Carta. Entendia o Relator que sem abstrair esses sentimentos, que, como disse, são legítimos, deveríamos pensar menos no passado e no presente e mais no futuro deste País. Por esta razão, enfrentamos com desassombro as questões

\footnotetext{
${ }^{17}$ Trecho de depoimento verbal de Ottomar Pinto, registrado em Ata da Subcomissão IV-B da Assembleia Nacional Constituinte, de 5 maio 1987, na cidade de Brasília, DF, arquivada no Senado Federal.
} 
delicadas, questões mal compreendidas (FIUZA, 1987, comunicação verbal) $)^{18}$.

Nós não podemos pensar numa Constituição voltada para aspectos conjunturais, para os ressentimentos bem próximos, para as nossas idiossincrasias recentes. A Constituição, V. Ex. ${ }^{a}$ sabe, tem que ser um instrumento de estruturação da sociedade brasileira. Então, não é possível enxertar casuísmos (PINTO,1987, comunicação verbal) ${ }^{19}$.

Por mais que todos os parlamentares presentes na subcomissão reconhecessem que o período anterior foi marcado por autoritarismo e violência, a defesa dos motivos originais que levaram as forças armadas a intervir na vida política nacional ajudou a sustentar a hipótese de que o passado recente fora marcado por muitos erros de todas as parcelas da sociedade brasileira, o que exigiria um esforço de superação baseado no olhar para o futuro e o esquecimento das feridas então abertas. Reforçava-se assim a lógica dos excessos, segundo a qual os militares passaram dos limites na repressão, mas apenas porque os grupos da esquerda também se valeram da violência política para disputar seus objetivos na sociedade.

V. Ex. ${ }^{a}$ disse que foi injustiçado porque defendia a Pátria com a força e eu digo: "pela força". V. Ex. a, que é homem sério e bem intencionado, não é o repositório da verdade universal; V. Ex. ${ }^{a}$ se constitui uma minoria que defendia os seus princípios, que julga ser os da Pátria, pela força obviamente, sofreram a repressão, porque saíram dos limites, tanto os militares, quanto V. Ex. ${ }^{\text {a }}$ É o meu enfoque, em que pese o respeito que tenho aos idealistas (FIUZA, 1987, comunicação verbal) ${ }^{20}$.

Em sua perspectiva, os excessos ocorridos no combate ao comunismo não podiam determinar a construção do novo texto constitucional. Ao evocar a noção de excessos, esvaziavam o caráter sistemático da repressão política e responsabilizavam os operadores da ponta por eventuais violações. Tal operação discursiva

\footnotetext{
${ }^{18}$ Trecho de depoimento verbal de Ricardo Fiuza, registrado em Ata da Subcomissão IV-B da Assembleia Nacional Constituinte, de 1 jun. 1987, na cidade de Brasília, DF, arquivada no Senado Federal. ${ }_{19}$ Trecho de depoimento verbal de Ottomar Pinto, registrado em Ata da Subcomissão IV-B da Assembleia Nacional Constituinte, de 23 abr. 1987, na cidade de Brasília, DF, arquivada no Senado Federal. ${ }^{20}$ Trecho de depoimento verbal de Ricardo Fiuza, registrado em Ata da Subcomissão IV-B da Assembleia Nacional Constituinte, de 1 jun. 1987, na cidade de Brasília, DF, arquivada no Senado Federal.
}

era imprescindível para dispensar a necessidade de uma revisão mais densa da estrutura institucional vigente. Diversas vezes eles falaram na necessidade de abandonar ressentimentos ou mágoas dos setores progressistas. Dessa maneira, os parlamentares do bloco conservador classificavam como emotivas quaisquer referências feitas às violações do período anterior, desqualificando de antemão a possibilidade de discutir os caminhos pelos quais o Estado brasileiro construiu um sistema voltado exclusivamente para a operação da repressão política. $\mathrm{Na}$ argumentação dos constituintes do bloco conservador, os eventos ocorridos no passado recente não poderiam servir como razão para desarmar o Estado dos instrumentos considerados necessários à sua defesa. Contudo, embora defendessem a necessidade de superar as feridas do passado recente, os parlamentares do bloco conservador tiveram na tradição seu argumento central. Por mais que ressaltassem como imperativo o olhar para o futuro, não deixavam de se ancorar nas soluções tipicamente brasileiras que se formularam ao longo de muitos anos para defender suas teses de preservação das formas de organização do Estado então vigentes.

Segundo os militares que compareceram a audiências na Subcomissão e de acordo com os próprios parlamentares que defenderam a doutrina, o conceito de segurança estaria ligado à possibilidade de identificar um conjunto de objetivos nacionais permanentes. Esses objetivos derivariam das características mais estruturantes da nacionalidade brasileira, tal como no realismo político. Em formulação próxima aos postulados do realismo político, portanto, a doutrina de segurança nacional sustentaria que o Estado era um espaço de realização da nação, assegurando as condições para a concretização de seus objetivos nacionais permanentes, compreendidos a partir do conhecimento das características nacionais.

Então, o problema talvez se situe menos no excesso de medo do intervencionismo militar do que naquilo que V. Ex. ${ }^{\text {a }}$ explicitou aqui, o fortalecimento do poder civil, das estruturas partidárias. $\mathrm{Na}$ hora em que essas coisas acontecerem, na hora em que tivermos, concomitantemente com isso, um modelo econômico mais justo, menos iníquo, não haverá por que pensar em pronunciamento militar, intromissões militares nas decisões da vida política brasileira. É essa a minha colocação, não vejo porque, por medo, por discriminação devamos dar uma volta de 180 graus em relação às tradições e à cultura brasileira, alijando as Forças Armadas 
do processo da segurança interna. Sabemos, foi dito aqui, que essa doutrina da segurança nacional tem alguns fundamentos, entre eles o seguinte: "a Nação busca a unidade", daí por que os objetivos nacionais permanentes que devem ser fixados pelo Congresso - são evidentes, óbvios, dizem respeito à sobrevivência do Estado-nação, e tudo aquilo que tender a sacrificar a sobrevivência nacional estará agredindo um objetivo nacional permanente, impulsionando na área de segurança interna, quando se tratar de adversários internos. E essa iniciativa das Forças Armadas, aí, seria subsidiária à das forças públicas: polícias militares e civis (PINTO, 1987, comunicação verbal) $)^{21}$.

Nessa proposta, seguir-se-ia concebendo o Estado como o espaço de realização da nação, dotada de objetivos permanentes e identificáveis a partir da análise de suas características culturais. É essa a base do argumento da tradição, que olhando para o que existe, reafirma a realidade em forma de objetivo, entendendo-a como única possibilidade de organização da vida social e política.

\section{Justiça de transição: defesa do passado e do militarismo nos discursos da CNV}

Durante a constituinte as falas de atores conservadores em sua maioria ex-militares ou ligados às forças armadas do Estado - marcaram uma narrativa sobre o passado que, em última instância, legitimava a exceção dos atos repressivos do regime anterior, quando não os classificava apenas sob o signo dos excessos, em nome da ordem. No período democrático, já sob o signo de políticas de justiça transicional, o tom do discurso militar manteve-se o, sendo sustentadas as mesmas linhas de argumentação que deram suporte aos esforços repressivos de antes.

Em 21 de dezembro de 2009, o então presidente Luiz Inácio Lula da Silva assinou o Decreto no 7.037, instituindo o terceiro Programa Nacional de Direitos Humanos (PNDH-3). Em seu eixo orientador VI Direito à memória e à verdade -, o programa estabelece três diretrizes para o esclarecimento do passado histórico brasileiro, particularmente no que se refere ao período autoritário inaugurado pelo golpe civil-militar de 1964. Essas diretrizes são: reconhecimento da memória

\footnotetext{
${ }^{21}$ Trecho de depoimento verbal de Ottomar Pinto, registrado em Ata da Subcomissão IV-B da Assembleia Nacional Constituinte, de 5 maio 1987, na cidade de Brasília, DF, arquivada no Senado Federal.
}

e da verdade como Direito Humano da cidadania e dever do Estado; preservação da memória histórica e a construção pública da verdade; e modernização da legislação relacionada com a promoção do direito à memória e à verdade, fortalecendo a democracia.

A primeira legislação a lidar com a temática da repressão política após a Constituição de 1988 foi a Lei no 9.140/1995, que reconheceu a responsabilidade do Estado brasileiro pelo desaparecimento de 136 opositores do regime civil-militar de 1964. Além dessa lista inicial, a lei instituiu uma comissão especial encarregada de examinar outros casos de vítimas da repressão, concedendo indenizações aos que julgasse procedentes. Posteriormente, em agosto de 2001, a Medida Provisória no 2.151-3 criou a Comissão de Anistia do Ministério da Justiça. Em novembro de 2002, esse marco legal foi convertido na Lei $\mathrm{n}$ 10.559/2002. Em novembro de 2011 foi sancionada a Lei no 1.2528 , que determinou a criação da Comissão Nacional da Verdade, instituída em maio de 2012. A comissão respondia à condenação internacional do Brasil no caso Gomes Lund vs. Brasil, quando o Estado brasileiro foi julgado pela Corte Interamericana de Direitos Humanos. Dentre as muitas frentes de trabalho abertas no âmbito desta iniciativa, o registro de depoimentos consiste um dos mais ricos para a compreensão do período autoritário 1964-1985.

Provavelmente os discursos produzidos pelos militares e agentes do Estado articulam conceitos e ideias que podem ser encontrados nos meios de comunicação, em trabalhos acadêmicos e outros tantos meios de formulação, expressão, reprodução e difusão de enunciados em nossa sociedade. Foram prestados à Comissão Nacional da Verdade e as comissões estaduais e setoriais de verdade e memória em parceria com a CNV aproximadamente 1177 depoimentos. Nesse total estão incluídos os depoimentos e testemunhos de vítimas e familiares de vítimas civis e militares da ditadura, especialistas, testemunhas, colaboradores institucionais, familiares de agentes institucionais civis e militares e agentes institucionais civis e militares ${ }^{22}$. Aproximadamente metade dos depoimentos levantados é composto exclusivamente por testemunhos de vítimas

\footnotetext{
${ }^{22}$ Os depoimentos podem ser encontrados junto ao Arquivo Nacional, no projeto Memórias Reveladas. Os números apresentados aqui foram obtidos por este autor, que trabalhou como analista de pesquisa da CNV. Após a entrega do relatório final, este pesquisador permaneceu na equipe de organização do acervo, constando entre os responsáveis pela reunião, classificação e edição dos depoimentos e testemunhos colhidos pela comissão. Disponível em: http://cnv.memoriasreveladas.gov.br/todos-volume1/650-agentes-p\%C3\%BAblicos.html. Acesso em: 28 jan. 2019
} 
diretas ou indiretas do regime, sejam elas civis ou militares, e pessoas que testemunharam algum tipo de violação aos direitos humanos no período.

Os depoimentos prestados por agentes do regime e por pessoas ligadas a eles, como familiares, compõem um total de aproximadamente 140 relatos. Mais de 80 deles são de agentes institucionais militares (agentes das Forças Armadas, policiais militares), pouco mais de 20 de agentes institucionais civis atuantes na repressão (delegados do DOPS, policiais federais, policiais civis) e 6 são de colaboradores institucionais do regime que não necessariamente ocupavam algum cargo dentro de qualquer órgão do Estado. O restante desses 140 depoimentos é constituído de relatos de familiares de agentes, de testemunhas militares e agentes institucionais civis que não atuavam em órgãos ligados diretamente ao esquema repressivo (funcionários do Ministério da Educação, diplomatas e outros). Mais de 90 desses depoimentos foram colhidos reservadamente.

Em comparação ao número de testemunhos prestados por vítimas, familiares de vítimas, especialistas e testemunhas, o número de agentes ouvidos é bastante reduzido. Muito disso se deveu ao não comparecimento de grande parte desses agentes, apesar de terem sido convocados. A recusa em depor já é um dado em si, relevante para a compreensão da relação que muitos deles estabeleceram com o tema da violência política e do lugar que ocuparam nas estruturas repressivas. Enquanto alguns militares reivindicam seu papel na concretização dos esforços repressivos, construindo um discurso de legitimação do mesmo, outros preferem o silêncio, recusando o sentido de disputa pública sobre o tema. Uma parcela significativa dos agentes após ter sido convocada a depor compareceu, mas não respondeu às perguntas elaboradas pela $\mathrm{CNV}$ ou deu qualquer tipo de informação voluntária. Muito dessa recusa pode ter relação com o temor de futuros processos de responsabilização judicial sobre as graves violações aos direitos humanos, mas algo pode ter relação com o tipo de leitura que desenvolveram do período.

Nos depoimentos prestados pelos militares à $\mathrm{CNV}$, bem como em outros espaços de fala desses atores, destacam-se alguns conceitos, como "guerra", "inimigo" e "ordem". Esses três elementos se articulam na fala de quase todos os militares ouvidos, funcionando como um canal para que os postulados abstratos da DSN ganhem materialidade na análise do passado de repressão política em que estiveram diretamente envolvidos estes atores. Dos muitos conceitos que compõem o amplo léxico militar do período (subversivo, terrorista, pátria, soberania, entre tantos outros), esses três são que parecem ter maior centralidade, além de serem os que permanecem ativos como definidores de uma cultura política que legitima o uso da violência por parte do Estado e implica, de certa maneira, numa concepção restritiva de política. O trinômio "guerra", "inimigo" e "ordem" é característico da visão de mundo "militar", sempre baseada em uma lógica que constrói uma identidade por oposição ao "mundo civil" (CASTRO, 2009).

Dentre os três conceitos aqui abordados como estruturantes da cultura política que envolve os militares do período, "guerra" é certamente o mais central. Ele aparece na fala de quase todos os militares ouvidos pela CNV e é recorrentemente empregado em outros espaços onde os militares manifestam sua visão sobre o envolvimento com a repressão. "Nós vivíamos numa época de enfrentamento, é sabido de todos, então, as notícias que saíam no jornal a respeito de qualquer coisa a respeito disso era objeto de análise de confronto" (Zilson Luis Pereira Da Cunha, 2014, informação verbal) ${ }^{23}$. Como se nota, parte importante da produção de uma narrativa baseada na ideia de guerra contra os "subversivos" ou "terroristas" tem a ver com a construção de um inimigo poderoso, dotado de recursos financeiros e militares que justifiquem tamanho esforço por parte do Exército brasileiro. O discurso que sustenta a existência de uma guerra vem acompanhado da ideia de que há certa suspensão dos parâmetros éticos e morais que regem a vida considerada normal do país, passando a valer um código próprio aos tempos de guerra. Em depoimento à $\mathrm{CNV}$, a esposa do médico militar Amilcar Lobo relata que seu companheiro se sentia culpado pelas funções que exercia e ilustra esse dilema moral a partir de um diálogo que presenciou: "O Amílcar sai da sala e vai para o jardim, e o Sampaio vai atrás dele e diz: "Lobo, nós estamos em um período de guerra, e guerra é isso" (Maria Helena Gomes de Souza 2014, informação verbal ${ }^{24}$.

A consolidação de um discurso sobre o que significa viver em "tempos de guerra" vem acompanhada de uma

\footnotetext{
${ }^{23}$ Trecho da transcrição do depoimento de Zilson Luiz Pereira Cunha à Comissão Nacional da Verdade, em 1 ago. 2014, Rio de Janeiro, RJ, Brasil. Disponível em: http://cnv.memoriasreveladas.gov.br/ images/pdf/depoimentos/agentes_publicos/Zilson_Luiz_Pereira_ da_Cunha_-_01.08.2014___ct_rp.pdf. Acesso em: $1 \overline{4}$ ago. 2019.

${ }_{24}$ Trecho da transcrição do depoimento de Maria Helena Gomes de Souza à Comissão Nacional da Verdade, em 7 maio 2014, Rio de Janeiro, RJ, Brasil. Disponível em: http://cnv.memoriasreveladas. gov.br/images/pdf/depoimentos/testemulhas/Maria_Helena_ Gomes_de_Souza.pdf. Acesso em: 14 ago. 2019.
} 
noção de sacrifício que se relaciona muito mais com o que se está disposto a fazer - ou até que ponto se está disposto a abrir mão de sua própria condição de sujeito moral - do que com o grau de abnegação em relação à própria vida. Em tempos de guerra, mais importante do que a disposição de morrer, é a disposição de matar.

Agora uma coisa que é interessante, o soldado é o mesmo em qualquer lugar do mundo, essa que é a verdade. O soldado é aquele homem que está preparado não é para morrer pela pátria, morrer pela pátria quem morre é amador, matar pela pátria, você entendeu? E quando a gente vai para essas coisas aí fora, a gente vê isso claramente, nós não queremos que os nossos filhos sirvam o Exército para morrer pela pátria, é ou não é? Agora se eles gostam daquilo, nós queremos que eles sejam exímios matadores, é ou não é verdade? (Álvaro de Souza Pinheiro, 2013, informação verbal). ${ }^{25}$

A guerra é apresentada como o espaço por excelência da exceção, como se a defesa da ordem exigisse a suspensão da mesma, ainda que de maneira seletiva, em determinados espaços e com referência a determinados cidadãos."[...] será que tem nexo você pegar um sujeito que é um terrorista, um camarada caçado, um camarada que não tem o que perder, que tem uma vida clandestina, que se afastou de sua família, tem cabimento enterrar ele em um cemitério? Eu não vejo" (Álvaro de Souza Pinheiro, 2013, informação verbal). ${ }^{26}$

É importante ressaltar que ao superdimensionar a ameaça a ser enfrentada, os militares justificam um complexo sistema de instituições e normativas repressivas que funcionava por todo o país. A construção de um inimigo muito poderoso é peça central do processo de legitimação da violência por parte do Estado: dado que se enfrentava uma "guerra" contra um "inimigo" poderoso, certos parâmetros morais eram suspensos e determinados "excessos" tolerados.

$\mathrm{Na}$ perspectiva dos militares, este inimigo teria sido o responsável por arrastá-los a uma guerra que

\footnotetext{
${ }^{25}$ Trecho da transcrição do depoimento de Álvaro de Souza Pinheiro à Comissão Nacional da Verdade, em 12 nov. 2013, Rio de Janeiro, RJ, Brasil. Disponível em: http://cnv.memoriasreveladas. gov.br/images/pdf/depoimentos/agentes publicos/Alvaro de Souza_Pinheiro_-_12.11.2013__rp.pdf. Acesso em: 14 ago. 2019. ${ }^{26}$ Trecho da transcrição do depoimento de Álvaro de Souza Pinheiro à Comissão Nacional da Verdade, em 12 nov. 2013, Rio de Janeiro, RJ, Brasil. Disponível em: http://cnv.memoriasreveladas. gov.br/images/pdf/depoimentos/agentes_publicos/Alvaro_de Souza_Pinheiro_-12.11.2013 _-_rp.pdf. Acesso em: 14 ago. 2019.
}

não queriam lutar ${ }^{27}$. Entretanto, uma vez em estado de combate era importante tratá-los com dureza e garantir sua derrota, mesmo que o custo pudesse ser a destituição de sua cidadania e das prerrogativas e direitos que pudessem lhes competir como brasileiros. A partir desse diagnóstico, a medida de quem é ou não um inimigo é dada pela sua relação com a ordem instituída, observada em espaços tão variados como um grupo de debates acadêmico, uma associação de bairro ou um sindicato. Se a "guerra" é um meio, um estado de coisas, e o "inimigo" é um sujeito, a manutenção da "ordem" é um objetivo. A preservação da ordem foi o grande objetivo dos militares e agentes do Estado envolvidos com a repressão política.

Como gritar? Se gritar, você ouve depois? Não é assim, não. A gente estava preocupado com trabalhar. Eu trabalhava e muito lá, para poder fazer o quê? A gente ouvia as pessoas que queriam subverter a ordem, queriam prejudicar o país, queriam trabalhar do outro lado e todo esse pessoal. Nós éramos os defensores da lei, que defendíamos essas pessoas que queriam a liberdade e não tinham por causa desses terroristas que estavam por aí solto (Alcides Singillo, 2014, informação verbal). ${ }^{28}$

A confusão entre ordem, pátria, soberania, governo e Estado prevalece na narrativa dos militares, mas não no sentido de equívoco ou de erro inconsciente e desinformado e sim no de alinhamento, convergência ou confluência entre estes elementos. Novamente a partir da Doutrina de Segurança Nacional, o discurso dos militares trata o Brasil como naturalmente alinhado ao bloco ocidental no contexto da Guerra Fria, o que implica na reafirmação do país como cristão e também democrático.

\begin{abstract}
Então, nós estávamos cientes que nós estávamos lutando para preservar a democracia. Nós estávamos lutando contra o comunismo. Nós estávamos lutando, como disse Elio Gaspari, para que isso aqui não se transformasse um enorme "Cubão". Se não fosse a nossa luta, se nós não tivéssemos derrotado,
\end{abstract}

\footnotetext{
${ }^{27}$ Apenas para registro vale lembrar que o relatório final da Comissão Nacional da Verdade, além de trabalhos acadêmicos, demonstra que a repressão política e as práticas de tortura, sequestro e assassinato seletivo são anteriores à formação de grupos armados de enfrentamento à ditadura.

${ }_{28}$ Trecho da transcrição do depoimento de Alcides Singillo à Comissão Nacional da Verdade, em 1 set. 2014, Rio de Janeiro, RJ, Brasil. Disponível em: http://cnv.memoriasreveladas.gov.br/ images/pdf/depoimentos/agentes_publicos/Alcides_Singillo _-_01.09.2014__rp.pdf Acesso em: 14 ago. 2019.
} 
hoje eu não estaria aqui, porque eu já teria ido para o paredão. Hoje não existiria democracia neste país. Os senhores estariam sob um regime comunista tipo Fidel Castro. Mas eu estou aqui porque nós vencemos, nós lutamos pela democracia. E os nossos inimigos, os terroristas, foram eleitos pelo voto dentro da democracia que nós preservamos e por isso dentro da democracia eu estou aqui nesse momento (Carlos Alberto Brilhante Ustra, 2013, informação verbal). ${ }^{29}$

O tema da ordem aparece sempre associado a uma concepção de democracia que prescinde do conflito como dinâmica constitutiva da política.

A defesa da democracia associada à defesa da ordem implica numa visão de política que entende o dissenso como perturbação e ameaça, como se a sociedade fosse homogênea e sem interesses divergentes por parte dos distintos grupos sociais. A concepção estreita de democracia implicada nos discursos dos militares fica evidente na fala do comandante da marinha Uriburu Lobo da Cruz, quando ao comentar sua participação na repressão à guerrilha do Araguaia ele afirma que os militares foram lá para "manter a ordem daquela região e impedir desordens que perturbassem a democracia". É curioso perceber que os militares envolvidos com a repressão seguem empregando as mesmas categorias em suas análises do período democrático que sucedeu a ditadura

Olha, se você pesquisar, você vai ver que no país milhares de pessoas desaparecem. Naquela época, comparando, foi meia dúzia de desaparecidos. Se você pesquisar vai ver que é milhares. Se você chegar nas delegacias de polícia, você vai ver que a prática de tortura é mais ou igual do que a época de ditadura. O crime aumentou de uma maneira... Então, prevalece até hoje. Cada dia crescendo mais, o sistema. E o que precisa acontecer, não é? É ter um basta nisso aí. Hoje nós temos segurança? Ninguém tem hoje (Cláudio Antônio Guerra, 2014, informação verbal $).{ }^{30}$

\footnotetext{
${ }^{29}$ Trecho da transcrição do depoimento de Carlos Alberto Brilhante Ustra à Comissão Nacional da Verdade, em 10 maio 2013, Rio de Janeiro, RJ, Brasil. Disponível em: http://cnv.memoriasreveladas. gov.br/images/documentos/Capitulo 15/Nota\%2039\%20-\%20 00092.000666 2013-17.pdf. Acesso em: 14 ago. 2019.

30 Trecho da transcrição do depoimento de Cláudio Antônio Guerra à Comissão Nacional da Verdade, em 23 jul. 2014, Rio de Janeiro, RJ, Brasil. Disponível em: http://cnv.memoriasreveladas.gov.br/ images/pdf/depoimentos/agentes_publicos/Claudio_Antonio_ Guerra_-_23.07.2014___ct_rp.pdf. Acesso em: 14 ago. 2019.
}

A ocupação de espaços institucionais ou sociais de relevância por parte de militares envolvidos com a repressão foi um ponto fundamental para que se processasse essa adaptação entre uma representação política do social que articulava guerra, inimigo e ordem no passado e no presente. Mas mais importante do que isso é entender como essa visão de mundo deixa os círculos militares e passa a organizar uma cultura política mais ampla. Contribui com isso o fato de que destacados repressores como Aluísio Madruga de Moura e Souza tenham ocupado cargos como a chefia de gabinete da Secretaria Nacional Antidrogas (SENAD, até 1997). Caberia seguir, como agenda de pesquisa, a trilha dos cargos ocupados, já na democracia, por alguns daqueles que enunciaram os discursos legitimadores da violência de Estado. Certamente muitos deles continuaram em espaços centrais do Estado brasileiro, até mesmo na política partidária.

\section{Considerações finais}

O presente trabalho pretendeu discutir, por meio da análise de fontes, como o discurso militar, em dois diferentes momentos, manteve dentre suas características uma articulação entre as noções de excessos, exceção e ordem. Em defesa de uma concepção vaga, mas ativa de ordem, eles se engajaram em processos repressivos que organizaram parcelas do aparelho do Estado para o uso sistemático da violência. Estes processos aparecem no discurso ora como excessos cometidos na ponta do sistema, ora como exceções legítimas ao arcabouço legal, uma vez que a defesa da ordem por vezes exige o emprego de expedientes não previstos legalmente, em particular quando a situação é análoga à uma guerra. Os discursos que permitem perceber esta articulação foram buscados nas discussões em torno das forças armadas do Estado na constituinte de 1987-8 e, mais adiante, nos depoimentos prestados à Comissão Nacional da Verdade (CNV). Transição e justiça transicional aparecem aqui interpeladas pelas narrativas que justificam, em um momento como no outro, o emprego continuado da violência.

Tanto no período da transição quanto no auge dos mecanismos de justiça transicional, os militares preservaram suas posições em defesa da ordem, buscando assim legitimar as ações de emprego da violência no passado recente. Essa defesa da ordem se apoiou no uso da violência física, apresentada ora como excesso, ora como exceção e, em alguns casos, como ambos. Enquanto a argumentação em torno 
dos excessos apontava para o despreparo de agentes na ponta do sistema, atuando sob forte pressão em ambiente de conflito, a lógica da exceção afirmava o tempo inteiro que os cidadãos cujos direitos foram violados eram, na realidade, combatentes e, portanto, conscientes da disposição ao sacrifício típica das guerras. No limite, sustenta-se que, mais do que a lei, deve ser a ordem a baliza que determina a condição da cidadania. Não é possível constituir uma linguagem de direitos, de procedimentos e, logo, de democracia quando os operadores da violência se movem com base em critérios políticos puramente substantivos, orientados por essa concepção de ordem que nunca se deixa definir por completo, que nunca se materializa na forma da lei. Sua indefinição é a medida de sua operacionalidade pelos detentores da força que, no entanto, não vacilam em identificar seus alvos. A duplicidade que, em toda parte, caracteriza os estados nacionais encontra abrigo confortável no Brasil, onde violência privada e pública convivem de mãos dadas, onde o legal e o para-legal caminham lado a lado. Parte da tarefa de uma justiça transicional é desmontar esse circuito, também discursivo, que constrói tijolo a tijolo a noção de ordem que nos preside.

\section{Referências}

ASSEMBLEIA NACIONAL CONSTITUINTE. Atas da Subcomissão IV-B, 1987. Brasília: Centro Gráfico do Senado Federal, 1987.

AB'SÁBER, Tales. Ordem e violência no Brasil. In: KUCINSKI, Bernardo et al. Bala perdida: a violência policial no Brasil e os desafios para sua superação. São Paulo: Boitempo Editorial, 2015.

ADORNO, Sergio. Direitos Humanos. In: OLIVEN, Ruben George et al. A Constituição de 1988 na vida brasileira. São Paulo: Aderaldo \& Rothschild Editores; Anpocs, 2008. p. 191-224.

AGAMBEN, Giorgio; BURIGO, Henrique. Homo sacer, o poder soberano e a vida nua I. Belo Horizonte: Ed. UFMG, 2007.

ANSALDI, Waldo; GIORDANO, Verónica (coord.). América Latina: Tiempos de Violencias. Buenos Aires: Ariel, 2014. 368 p.

BATISTA, Vera Malaguti. Direitos (e) Humanos no Brasil Contemporâneo. Jura Gentium, [s. l.], v. 1, 2008.

BATISTA, Vera Malaguti. Introdução crítica à criminologia brasileira. Rio de janeiro: Revan, 2011. p. 90.

BATISTA, Vera Malaguti. Estado de polícia. In: KUCINSKI, Bernardo et al. Bala perdida: a violência policial no Brasil e os desafios para sua superação. São Paulo: Boitempo Editorial, 2015 .
BAUER, Caroline Silveira. Um estudo comparativo das práticas de desaparecimento nas ditaduras civil-militares argentina e brasileira e a elaboração de políticas de memória em ambos os países. Tese (Doutorado em História) - Programa de Pós-Graduação em História, UFRGS, Porto Alegre, 2011.

BRASIL. Justiça de Transição no Brasil: o papel da Comissão de Anistia e do Ministério da Justiça. Revista Anistia, Brasília, n. 1, p. 12-23, 2009.

CASTRO, Celso; D'ARAUJO, Maria Celina; SOARES, Gláucio Ary Dillon. Os anos de chumbo: a memória militar sobre a repressão. Rio de Janeiro: Relume-Dumará, 1994.

CASTRO, Celso; D’ARAUJO, Maria Celina; SOARES, Gláucio Ary Dillon. A volta aos quartéis: a memória militar sobre a abertura. Rio de Janeiro: Relume-Dumará, 1995.

CASTRO, Celso; LEIRNER, Piero. Antropologia dos militares: reflexões sobre pesquisas de campo. Rio de Janeiro: FGV, 2009.

COIMBRA, Cecília. Doutrina de segurança nacional e produção de subjetividade. Clínica e política: subjetividade e violação dos direitos humanos. Rio de Janeiro: Instituto Franco Basaglia/ TeCorá, 2002.

FICO, Carlos. Como eles agiam: os subterrâneos da Ditadura Militar: espionagem e polícia política. Rio de Janeiro: Record, 2001.

GRAHAM, Stephen. O bumerangue de Foucault: o novo urbanismo militar. In: KUCINSKI, Bernardo et al. Bala perdida: a violência policial no Brasil e os desafios para sua superação. São Paulo: Boitempo Editorial, 2015.

IASI, Mauro Luis; COUTINHO, Eduardo Granja (org.). Ecos do golpe: a persistência da ditadura 50 anos depois. Rio de Janeiro: Mórula, 2014.

KARAM, Maria Lucia. Violência, militarização e 'guerra às drogas'. In: KUCINSKI, Bernardo et al. Bala perdida: a violência policial no Brasil e os desafios para sua superação. São Paulo: Boitempo Editorial, 2015.

KOSELLECK, Reinhart. Futuro passado: contribuição à semântica dos tempos históricos. Rio de Janeiro. Contraponto: Ed. PUC-Rio, 2006.

LESSA, Renato. In: DINIZ, Eli; BOSCHI, Renato Raul; LESSA, Renato. Modernização e consolidação democrática no Brasil: dilemas da Nova República. São Paulo: Vértice, 1989.

O'DONNELL, Guillermo; SCHMITTER, Philippe C. Transições do regime autoritário: primeiras conclusões. São Paulo: Vértice, 1988.

PERRUSO, Marco Antônio. Em Busca do Novo: intelectuais brasileiros e movimentos populares nos anos 70/80. São Paulo: Annablume, 2009.

PILATTI, Adriano. A Constituinte de 1987-1988: progressistas, conservadores, ordem econômica e regras do jogo. Rio de Janeiro: Lúmen Júris, 2008. 
PINHEIRO, Paulo Sérgio. Continuidade autoritária e construção da democracia: Relatório final. São Paulo: NEV-USP, 1999.

PEREIRA, Coronel Íbis. Os lírios não nascem da lei. In: KUCINSKI, Bernardo et al. Bala perdida: a violência policial no Brasil e os desafios para sua superação. São Paulo: Boitempo Editorial, 2015.

SAFATLE, Vladimir. Do uso da violência contra o estado ilegal. In: TELES, Edson; SAFATLE, Vladimir (org.). O que resta da ditadura. São Paulo: Boitempo Editorial, 2010.

SEGATO, Laura Rita. Las nuevas formas de la guerra y el cuerpo de las mujeres. Puebla: Pez en el árbol, 2014. https://doi. org/10.1590/S0102-69922014000200003

SOARES, Luiz Eduardo. Por que tem sido tão difícil mudar as polícias? In: KUCINSKI, Bernardo et al. Bala perdida: a violência policial no Brasil e os desafios para sua superação. São Paulo: Boitempo Editorial, 2015.

TADDEI, Jayme dos Santos. O militar e a democracia: profissionalização e visão de mundo. Tese (Doutorado) Instituto Universitário de Pesquisas do Rio de Janeiro (IUPERJ), Rio de Janeiro, 2008.

VIANNA, Luiz Werneck. Travessia: da abertura à constituinte. Rio de Janeiro: Livraria Taurus Editora, 1986.

ZAFFARONI, Raúl Eugenio. El crimen de Estado como objeto de la criminologia. In: REY, Sebastián Alejandro; FILARDI, Marcos Ezequiel (coord.). Derechos Humanos: reflexiones desde el sur. Buenos Aires: Infojus, 2012.

ZAVERUCHA, Jorge. Relações civil-militares: o legado autoritário da constituição brasileira de 1988. In: TELES, Edson; SAFATLE, Vladimir (org.). O que resta da ditadura. São Paulo: Boitempo Editorial, 2010.

Recebido em: 15/2/2019.

Aprovado em: 27/7/2019.

Publicado em: 25/11/2019.

Endereço para correspondência:

Pedro Rolo Benetti

Universidade de São Paulo (USP)

Av. Professor Luciano Gualberto, 158 - Butantã

05508-900, São Paulo, SP, Brasil

\section{Autor/Author:}

Pedro Rolo Benetti pedrorolobenetti@gmail.com

- Doutor em Ciência Política pelo Instituto de Estudos Sociais e Políticos da Universidade do Estado do Rio de Janeiro (IESP-UERJ). Pesquisador com bolsa de pós-doutordo no Núcco de . Estudos da Vis Foi analista de pesquisa da Comissa Nacional da Verdade (CN), pesquisador do Instituto de Politicas Puiblicas en Direitos Humanos do Mercosul (IIPD) e coordenator nacional de busc e identificação de desaparecidos políticos da Comissão Especial sobre Mortos e Desaparecidos Políticos (CEMDP)

(D) https://orcid.org/0000-0003-1396-8654

- $\mathrm{PhD}$ in Political Science from Institute of Social and Political Studies of the Rio de Janeiro State University (IESP-UERJ). Rresearcher with a postdoctoral fellowship in the Nucleus of Studies on Violence of University of Sao Paulo (NEV-USP), Sao Paulo, Sao Paulo, Brazil. Was a research analyst at the National Truth Commission (CNV), a researcher at the Institute of Public Policy on Human Rights of Mercosur (IPPDH) and national coordinator for the search and identification of political disappeared persons of the Special Committee on Political Deaths and Disappearances (CEMDP)

- Doctor en Ciencias Políticas por Instituto de Estudios Sociales y Políticos de la Universidad del Estado de Río de Janeiro (IESP-UERJ). Investigador con una beca postdoctoral en el Núcleo de Estudios sobre Violencia in Universidad de San Pablo (NEV-USP), San Pablo, SP, Brasil. Fue analista de investigación en la Comisión Nacional de la Verdad (CNV), investigador en el Instituto de Políticas Públicas en Derechos Humanos del Mercosur (IPPDH) y coordinador nacional para la búsqueda e identificación de desaparecidos políticos de la Comisión Especial sobre Muertos y Desaparecidos Políticos (CEMDP). 